\title{
Psychological Impact of Vesico-Vaginal Fistula on Reproductive Age Women and its Midwifery Implication in Lautech Teaching Hospital, Osogbo, Osun State
}

\section{Adefolake Monsurat Olatunde 1}

\author{
${ }^{1}$ Department Of Nursing, Faculty Of Clinical Sciences, College Of Medicine, University Of Ibadan \\ ${ }^{1}$ Department Of Nursing, Faculty Of Clinical Science, College Of Health Sciences, Ladoke Akintola University Of \\ Technology, Osogbo, Osun State
}

\begin{abstract}
The research focuses on the psychological impact of Vesico-vaginal fistula on reproductive age women in Lautech Teaching Hospital (LTH) Osogbo, Osun state. The research aims at investigating the psychological impact of Vesico-vaginal fistula on reproductive aged women as regards their age; educational status and place of abode. A descriptive research design was adopted for the study. A purposive sampling technique was used to select 53 respondents in the out-patient and gynecological units of LTH, Osogbo. Osun state and a self-designed questionnaire was used to collect data from the respondents. Three null hypotheses were tested using chi-square statistical method at 0.05 level of significance. The first two hypotheses were accepted meaning that there are no significant differences in psychological impact of VVF between young and middle age respondents and between educated and illiterate respondents while the third hypothesis was rejected meaning there is significant difference in psychological impact of VVF between respondents from urban and rural areas. In conclusion, nurses and midwives should be aware of the kind of nursing care that can be given to reduce the identified psychological impact of VVF on reproductive age women.
\end{abstract}

Keywords: Psychological; Vesico-vaginal; Reproductive-age; Lautech Teaching Hospital (LTH); Respondents; Nurses; Midwives

\section{INTRODUCTION}

Vesico-vaginal fistula (VVF) is a sub-type of female urogenital fistula (UGF). According to Martins (2003), VVF is an abnormal communication between the bladder and the vagina causing urinary incontinence often caused by prolonged labour process where the unborn child presses tightly against the pelvis, cutting off blood flow to the vesicovaginal wall that may necrotize the affected tissue, leaving a hole. He went further to state that VVF may also result from gynaecological operations e.g. hysterectomy, radiation damage following radiotherapy for pelvic malignancy and violent rape.

Russell et al., (2004), opined that VVF is a common condition which rapidly leads to loss of morale and serious social disruption in countries where surgical treatment is not readily available and some of the cause of VVF includes protracted or neglected labour; Gynecological operation such as total hysterectomy and anterior colporrhapy, radiotherapy used in the treatment of cervical cancer; direct infiltration of cervical cancer that ulcerates through the anterior fornix to implicate the bladder. They went further to state that if wound on the bladder wall is recognized and repaired at once, leakage is uncommon but fistula occurs when such damage passes unnoticed.

However, most VVF are the result of ischaemic necrosis of the bladder wall due to prolonged pressure of the fetal head in obstetric cases but in gynaecological cases, the ischaemia is brought about by grasping the bladder wall in a haemostat, including the bladder wall in a suture or perhaps even by local oedema or haematoma. Leakage due to necrosis of tissue seldom manifests itself before seven days after the operation. (http//:www.ncbi.nlm.nich.gov / pubmed; Accessed January 5, 2012). 
Trauma to the bladder may occur as a result of pressure from the fetal head during labour or as a result of trauma during delivery. VVF is still a common cause of morbidity in women especially in developing countries. Prolonged compression of the tissues causes necrosis of the bladder and vagina wall and result in urinary incontinence. Intrauterine infection may follow prolonged VVF. Untreated VVF following a traumatic birth can result in longterm psychological problem. (Fraser et al., 2005). They further stated that post-delivery VVF results in the client experiencing flash back of labour process, avoidance to prevent memories and an increased level of anxiety when in similar situation. Opportunities need to be given to the woman and her family to talk through their experience. Also, careful and detailed explanation to the woman is needed to help her understand and interpret events related to VVF.

The psychological trauma is caused by lowered selfesteem, stress, increased anxiety, depression, sense of powerlessness and loss of control over events related to VVF. Lack of information and failure to consent to management also add to the sense of disempowerment. The attitude of midwives and obstetricians also contributes to the distress if they are perceived by the woman as unsympathetic and uncaring. Debriefing and follow-up by trained counselors has been successful traumatic labour and delivery leading to VVF. (Fraser et al., 2006).

Taylor (2003), opined that patients diagnosed with VVF experience stress and emotional upheavals, fear of death, interruption of life plans, change in social roles, lifestyle and medical bills, are important issues to the faced.

Barbara et al., (2004), state that self-concept is one's mental image of oneself. A positive self-concept is essential to a person's mental and physical health. Individuals with positive self-concept are better able to develop and maintain inter-personal relationship and resist psychological and physiological illness. An individual possessing a strong self-concept would be better able to accept or adapt to change that may occur over their span. How one views oneself affects one's judgment of one's own worth, that person's standard and performances compares to other and to one's ideal self. If a person's self-esteem does not match with ideal self, then low self-esteem results.

Newel (2004), demonstrated that many factors may cause psychological stress in patients with VVF and stress is particularly likely to arise out of the effect and treatment of the condition which results in obvious alteration of the body function.

He went further to state that shock is often experienced by the woman when she realizes the nature of the changes in bodily function. She becomes concerned about how these changes will affect her relationship with members of her family, her friends and co-workers, this concern also extends to how these changes will affect her ability to make a living.

The research was conceived when the researcher worked in the gynecological ward and out-patient department with patients with VVF. It was noticed that they kept to themselves and are easily angered. They exhibited behavioural changes which were confirmed to commence after the condition had occurred. In an attempt to know what caused the behavioural changes which include isolation, dejection and withdrawal from the family members, it became imperative for the researcher to unveil the reasons for the above mentioned behaviours.

\section{Statement of the problem}

It has been realized that the rate of occurrence of VVF has increased due to increased in the incidence of prolonged or obstructed labour as well as other causes in our hospitals. For the purpose of this research study, the following questions were pertinent:

- Will educated patient with VVF experience the psychological impact more than illiterate patients?

- Will young adult with VVF experience the psychological impact more than middle adult patients?

- Will married patients with VVF experience the psychological impact more than single patients?

- Will patients in urban centre's with VVF experience the psychological impact more than those in rural areas?

Since it has been realized that VVF has impacts on the normal physiological and psychological functioning of reproductive-age women, the research study will serve to enlighten women on the causes and prevention of VVF. The study will also help to correct any misconceptions about VVF and boost women's knowledge about it thereby adding to the body of knowledge of the nursing profession.

\section{Purpose of the Study}

The purposes of the study are:

- To highlight the most prevalent psychological problems associated with VVF.

- To provide a better understanding of the psychological problems experienced by patients with VVF.

- To describe the psychological impact of VVF on some selected patients in LTH, Osogbo.

- To widen the horizon of the researcher's knowledge about the effect of VVF on reproductive age women. 
- To highlight the kind of nursing care that can be given to reduce the identified psychological and physiological impact.

\section{Research Questions}

The following questions are pertinent:

- "Will there be a difference in the psychological impact of VVF and married respondents compared with single respondents"?

- "Will there be a difference in psychological impact of VVF on respondents who had adequate information on its management compared to respondents who did not"?

- "Will there be a difference in psychological impact of VVF on respondents who had good family support compared to respondents who did not"?

\section{Research Hypothesis}

The following three null hypotheses will be tested in the research study at 0.05 level of significance;

- There is no significant difference in psychological impact of VVF on young respondents compared with middle-aged respondents.

- There is no significant difference in psychological impact of VVF between educated and illiterate respondents

- There is no significant difference in psychological impact of VVF between respondents from urban and rural areas.

\section{LITERATURE REVIEW}

\section{Meaning of VVF}

According to Smeltzer and Bare (2004), a fistula is an abnormal tortuous opening between two internal, hollow organs or between an internal organ and the exit of the body. The name of the fistula indicates the two areas that are connected abnormally. They went further to state that VVF is an opening between the bladder and the vagina. Fistula may be congenital in origin. In adults, however, break down usually occurs due to tissue damage, resulting from injury sustained during surgery, vaginal delivery, and radiation therapy or disease process such as carcinoma.

\section{Effects of VVF}

Chernecky and Berger (2005), stated that strong evidence exist that it is not the diagnosis of VVF parse that results in psychological impairment but rather the progression of the diseases condition. The level of psychological and physiological impairment and losses associated with VVF are important causes of depression and despair.

Taylor (2003), demonstrated that because VVF is sometimes long term and fatal in prognosis in the absence of poor management, problem of psychological adjustment to the disease condition may arise. The normal response to the diagnosis is denial or despair followed by distress and mixture of symptoms such as depressed mood, anxiety, insomnia, anorexia and irritability. Although, minority of VVF patients develop psychiatric illness, most of them experience psychological problems and these include fatigues, fear, problem of finance, employment, child care and other family worries as well as spiritual doubt (White \& Macleod, 2006)

Newell (2004), stated that many factors are responsible for the psychological problems associated with VVF. Stress is particularly likely to arise from the diagnosis of the disease condition and the obvious changes in body function. The patient experiences shock when she realizes the extent of the disease condition and the nature of the change in body function. She becomes concerned about how this change in body function will affect her relationship with family members, friends and co-workers. Her concern extends to how this change will affect her ability to make a living.

\section{Self - Concept of VVF Patients}

According to Barbara, Glenora, Audrey and Shirlee (2004), self-concept is one's mental image of one self. Self-concept involves all of self-perception, that is, appearance, values and beliefs that influence behavior. Self-concept is a complex idea that influence how one thinks, talks and; how one views and treats others; the choices one makes; one's ability to show love; one's ability to make choices and take actions. Nurses have the responsibility, not only to identify clients with negative self-concepts, but to also indentify the possible causes in orders to help people develop a more positive view about themselves. Individuals with poor self-concept may express feelings of worthlessness, self-dislike and hatred which may be projected to others. Individuals with poor self-concept may also feel sad or hopeless and state that they lack energy to perform even the simplest task.

They went further to state that there are four dimensions of self-concept which includes selfknowledge, self-expectation, social self and social evaluation. People who value "how I perceive me" above "how others perceive me" can be termed as "me-centered". They try hard to live up to their own expectations and compete only with themselves, not others. In contrast, strongly "others-centered, these people have a high need for approval from others and try to live up to the expectations of others, comparing, competing and evaluating themselves in relation to others. They tend not to deal with their personal short-coming, are unable to assert themselves and fear disapproval. The positive self- 
concept, "me-centered," is formed with minimal reference to other's opinions. Assessing and promoting a positive self-concept is not limited to the nurse acting on the client, the nurse's own selfconcept is also important. A nurse that understands the different dimensions of themselves are better able to understand the needs, desire and feelings of the client. A nurse that feels positive about herself is more likely to help the client meet her needs. According to the authors, a person is not born with self-concept, rather it develops as a result of social interaction with others and there are three broad steps in the development of self-concept which include learning the difference between physical self and the environment; internalizing other's attitude and internalizing the standards of the society.

\section{Components of Self-Concept}

There are four components of self-concept which includes personal identity; body image; role performance and self-esteem. Personal identity is the conscious sense of individuality and uniqueness that is continually evolving throughout life. People often view their identity in terms of name, sex, age, race, ethnic origin or culture and occupation or role. Personal identity also includes beliefs and values, personality and character. An individual with a strong sense of identity has integrated body image, role performance and self-esteem into a complete selfconcept. This sense of identity provides a person with a sense of continuity and a unity personality.

The individual sees himself as a unique person (Barbara, Glenora, Audrey \& Shirlee, 2004).

Body image is how a person perceives the size, appearance and function of the body and its parts. Body image has both cognitive and effective aspects. The cognitive aspect is the knowledge of the body and its attachments while the affective aspect includes sensation of the body such as pain, pleasure, fatigue and body movement. Body image is the sum total of attitudes, conscious and unconscious, that an individual has towards her body. Body image encompasses the functions of the body and its parts. A person's body image develops partly from other's attitudes and responses to that person's body and partly from the individual's own exploration of the body. An individual with a healthy body image will normally have concern for his or her health an appearance. This person will seek help if sick and will include health-promoting activities like sleep, exercise and balanced diet. The individual with negative body image may hide or not look at or touch his or her body part. Some individual may express feelings of helplessness, hopelessness, powerlessness and vulnerability and may exhibit self-destructive behaviours such as suicide attempt. (Barbara, Glenora, Audrey \& Shirlee, 2004). According to these authors, an individual undergoes role changes throughout life. A role is a set of expectations about how a person occupying a position should behave. Role performance relates to what a person in a particular position does to the behavior expected of that role while role mastery involves the individual's behaviours meeting social expectation.

Famakinwa (2002), stated that people require a stable self-esteem and feeling that others have a high regard for them. When this is not achieved, the individual feels inferior, weak and helpless. Satisfaction of selfesteem results in a positive feeling and the individual feels confident and useful to the community. Selfesteem is threatened by factors such as change in role, change in body image etc. In solving client's problem of self-esteem disturbance, the nurse must respect the client as an individual.

\section{Psychological Impact of VVF}

Taylor (2003), opined that anxiety is a problem, not only because it is intrinsically distressing but also because it can interfere with good functioning of the body. Anxious patients awaiting therapies may be debilitated by emotional distress even before therapy begins. Such patients cope poorly with the therapy. Anxiety is also high when people expect substantial life-style changes as a result of a diseases condition or its treatment.

He further stated that depression is a common and often debilitating reaction to a disease condition and its treatment. Assessing depression can be problematic as many of the physical signs of depression such as fatigue, sleeplessness and loss of weight, may also be symptoms of disease or side effects of the treatment. If depressive symptoms are attributed to illness or treatment, their significance may be less apparent and consequently, depression may go untreated.

Historically, the issue of VVF data back to 2050 B.C. when it was observed in the mummies of ancient Egypt. The first reference to fistula dates back to 1550 B.C and later linked to obstructed labour in 1030A.D. Between the $17^{\text {th }}$ and $19^{\text {th }}$ centuries, VVF was a problem in much of what is now known as the "developed countries" including U.S and Europe. This problem was tackled as social and economic development took place in the so-called developed continents. The year 1855 saw the establishment of the world's first VVF specialist hospital in New York. Mr. Sims, a famous VVF surgeon performed the first VVF repair there. In 1895, the hospital was converted to general hospital as incidence of VVF decreased with development. (http://www.ncbi.nlm.hih.gov/pub med; Retreived January 5, 2012). 
In Nigeria, however, the problem of VVF is increasing as the general development of the community worsens. Despite the availability of VVF repair facilities in some Nigerian hospitals for almost a century, the problem persists. This can be association with the general under-development of community health services structures and widespread poverty that has become ingrained in the live of majority of Nigerians. In rural areas, the prevalence rate is said to be higher due to inadequacy of facilities for pre-natal and post-natal care. In such areas, long distances combined with high cost of care, ignorance and poor nutrition makes women more vulnerable to VVF. Although it is certain that victim of this preventable condition can be found across the length and breadth of the country, there appears to be a high concentration in the northern region of the country. In Nigeria, an estimated 529,000 women died from the complications of pregnancy and child birth in 200. For every woman who dies, approximately 20 more are seriously injured or disabled. This means that every year, close to 9 million women suffer some type of injuries from pregnancy or childbirth that can have a profound effect on their lives and that of their families. (http://www.ncbi.nlm.nih.gov/pub med; Accessed January 7, 2012).

According to the federal ministry of health (FMOH), between 500,000 and 1,000, 000 women are living with VVF and an estimate of up to 80,000 new cases annually. The incidence is estimated at per 100 deliveries, these estimates are based on information gathered from victims who attend established medical facilities seeking health care. The reality is however that most sufferers, due to either distance or cost, never make it to any formal medical establishment for appropriate attention.

In addition to the physical problems, VVF causes acute, psychological and social problems. Due to constant leakage of urine and the accompanying smell, most communities consider these women as outcasts and cut them off from all social activities. Boarding public transport and engaging in social activities such as wedding and naming ceremonies becomes difficult. If the fistula is not repaired, her husband may divorce her. Some leave their family and room about the street of cities where they are not known as the out look for them remains bleak in the community. (http://www.ncbi.nlm.nih.gov/pubmed; Accessed January 7, 2012).

Most women suffer alone. Women attempt to manage the condition by using rags for protection or carrying a bowl between their legs. Husbands and community members regard the symptoms as a sign of infidelity, sexually transmitted disease or having been bewitched. Women try to hide their situation, making it impossible to partake in normal life or function within the community. If the fistula is not repaired, the woman remains incontinent and childless and is most likely to be abandoned by her husband, on whom she is economically dependent. She lives a life of rejection, depression, isolation, mental frustration and in most cases, she will die from complications of the condition. Most unfortunately, live in rural areas where corrective surgery is beyond their reach and some are restricted to travel by their husbands. (http://www.extended hands org; Retrieved January 9, 2012).

An obstetric fistula can be closed with intravaginal surgery. If surgery is performed by a skilled surgeon, a fistula patient has a good chance of returning bodily functions and ability to bear children. Proper antenatal care as well as delivery under the care of a trained health care provider will help to prevent VVF from developing. Education about nutrition and reproductive health will raise awareness on many of the factors that cause the condition (http://www.exteded hands, org; Retrieved January 9, 2012).

\section{MATERIALS AND METHODS}

This aspect of the study would encompass the following: Research design; research setting; Research population; Sample and sampling technique; Instrument for data collection; psychometric properties of the instrument; Type of data collection and data analysis; Ethical consideration and limitations.

\section{Research Design}

A description research design was adopted for this study because researcher is interested in describing the psychological impact of vesico-vagina fistula among reproductive age women in Lautech Teaching Hospital (LTH), Osogbo. Osun State.

\section{Research Setting}

The research was carried out in gynecology ward and out-patients unit of LTH, Osogbo, Osun State. It is a tertiary health institution concerned with curative health care delivery, research and education of medical students. It is located in Ajegunle, Olorunda local government area of Osun State and owned by both Oyo and Osun State government. It was established in 1999 by Osun state military administrator, Colonel Anthony obi. It has about 1,108 employees with 15 wards and a bed capacity of about 400. Some of the units include: Accident and emergency; Antenatal; Female surgical unit; Male orthopaedics unit; Paediatrics surgical unit; Gynaecology; Psychiatry; Out- patient clinic; Eye ward; Intense care unit; Burns, etc.

\section{Research Population}

The research populations for the researcher study 
were patients with VVF in the gynecology ward and out-patient unit of LTH, Osogbo, Osun State.

\section{Sample and Sampling Technique}

Purposive sampling technique was used to select 53 respondents from gynecological ward and out-patient unit of LTH, Osogbo, Osun State. The respondents include those patients on the ward and are being treated and nursed in the hospital and those on outpatient visits to the hospital. The respondents were grouped into literate and illiterate; young adult and the middle adult; those in rural area and those in urban areas; married and single respondents; those who had and did not have adequate information on management of VVF; and those who had and did not have good family support. Although, thumb's rule (30\% of the total population) should have been used, this was not possible due to the limited number of respondents available during the period of the research study.

\section{Instrument for Data Collection}

A self-designed questionnaire was used in the collection of data which was administered to reproductive-age women with VVF in gynecology ward and out-patient unit of LTH, Osogbo, Osun State.

The questionnaire has two sections namely:

Section A: Demographic data section which consist of seven batteries.

Section B: VVF / Psychological impact section which consists of twenty-three batteries.

\section{Psychometric Properties of Instrument}

The questionnaire was shown to the researcher's supervisor and face validity of it was determined by him. Also, pilot study, carried out Asubiaro State Hospital, Osogbo, Osun State, to determine the reliability of the instrument. The cronbach alpha yielded the reliability of 0.795 using SPSS version 16 among 12 patients in Asubiaro State Hospital meaning the instrument is reliable and can be used for the study.

\section{Type of Data Collection and Data Analysis}

Data collected was analysed using statistical analysis and percentage. Percentage was used to analyse the research questions while chi-square statistical test was used to test the null hypotheses at 0.05 level of significance.

\section{Ethical Consideration}

The ethical principles of respect for autonomy, nonmaleficience, beneficence and justice were considered as stated in The Declaration of Helsinki. A letter of introduction was collected from the head of Department of nursing, Ladoke Akintola University of Technology, Osogbo. Osun state, which was submitted and approved by the ethical committee of the hospital. Respondents were assured of confidentiality and use of the supplied answers to the questionnaire for academic and research purposes only.

\section{RESULTS AND DISCUSSION}

Section A

Table 4.1(Demographic data of respondents)

\begin{tabular}{|l|l|l|l|l|}
\hline S/N & & & Frequency & Percentage (\%) \\
\hline 1 & Age & Young adult (20 -40 years) & 31 & 58.5 \\
& & Middle adult (40-65 years) & & 41.5 \\
\hline 2 & Educational status & 22 & 58.5 \\
& & Literate & 31 & 41.5 \\
\hline 3 & Marital status & Illiterate & 22 & 69.8 \\
& & Married & 37 & 30.2 \\
\hline 4 & Occupation & Single & 16 & 69.8 \\
& & Political, & 37 & 11.3 \\
& & Self-employed & 6 & 7.3 \\
& & Students & 4 & 11.3 \\
\hline 5 & Religion group & & 6 & 75.5 \\
& & Christianity & 9.4 \\
& & Islam & 40 & 3.8 \\
\hline 6. & Ethnic group & Traditional & 5 & 11.3 \\
\hline 7. & Place of abode & Others & 2 & 77.4 \\
& & Yoruba & 6 & 15.1 \\
\hline
\end{tabular}


Psychological Impact of Vesico-Vaginal Fistula on Reproductive Age Women and its Midwifery Implication in Lautech Teaching Hospital, Osogbo, Osun State

From the table 4.1

- $31(58.5 \%)$ of the respondents were young adults. While $22(41.5 \%)$ were middle -age adults

- $31(58.5 \%)$ of the respondents were literate while $22(41.5 \%)$ were illiterate.

- $37(69.8 \%)$ of the respondents were married while $16(30.2 \%)$ were single.

- $37(69.8 \%)$ of the respondents were civil servants; $6(11.3 \%)$ were politician; $4(7.5 \%)$ were self-employed while 6 (11.3\%)
- $40(75.5 \%)$ of the respondents practice Christianity; 5 (9.4\%) practice Islam; 2 (3.8\%) were traditions while $6(11.3 \%)$ practice other religion.

- $41(77.4 \%)$ of the respondents were Yoruba tribe; $8(15.1 \%)$ were Igbo tribe while 4 $(7.5 \%)$ were Hausa tribe

- $9(17.0 \%)$ of the respondents lived in rural areas while $44(83.0 \%)$ lived in urban areas

\section{Section B}

Table 4.2 (VVF/Psychological impact of VVF)

\begin{tabular}{|c|c|c|c|c|}
\hline Variable & Frequency & Percent & $\begin{array}{l}\text { Valid } \\
\text { Percent }\end{array}$ & $\begin{array}{l}\text { Cumulative } \\
\text { Percent }\end{array}$ \\
\hline $\begin{array}{l}\text { VVF is the presence of hole in the vagina leading to } \\
\text { leakage of urine. } \\
\text { a) Yes } \\
\text { b) No }\end{array}$ & $\begin{array}{l}38 \\
15\end{array}$ & $\begin{array}{l}71.7 \\
28.3\end{array}$ & $\begin{array}{l}71.7 \\
28.3\end{array}$ & $\begin{array}{l}71.7 \\
100.0\end{array}$ \\
\hline $\begin{array}{l}\text { The diseases affect the psychological status. } \\
\text { a) Yes } \\
\text { b) No }\end{array}$ & $\begin{array}{l}48 \\
5\end{array}$ & $\begin{array}{l}90.6 \\
9.4\end{array}$ & $\begin{array}{l}90.6 \\
9.4\end{array}$ & $\begin{array}{l}90.6 \\
100.0\end{array}$ \\
\hline $\begin{array}{l}\text { The disease has impact on sexual activities } \\
\text { a) Yes } \\
\text { b) No }\end{array}$ & $\begin{array}{l}23 \\
30 \\
\end{array}$ & $\begin{array}{l}43.4 \\
56.6 \\
\end{array}$ & $\begin{array}{l}43.4 \\
56.6 \\
\end{array}$ & $\begin{array}{l}43.4 \\
100.0 \\
\end{array}$ \\
\hline $\begin{array}{l}\text { The disease has impact on life-styles and role } \\
\text { performance. } \\
\text { a) Yes } \\
\text { b) No } \\
\text { The condition affects the body image. } \\
\text { a) Yes } \\
\text { b) No }\end{array}$ & $\begin{array}{l}47 \\
6 \\
\\
28 \\
25\end{array}$ & $\begin{array}{l}88.7 \\
11.3 \\
52.8 \\
47.2\end{array}$ & $\begin{array}{l}88.7 \\
11.3 \\
52.8 \\
47.2\end{array}$ & $\begin{array}{l}88.7 \\
100.0 \\
52.8 \\
100.0\end{array}$ \\
\hline $\begin{array}{l}\text { I try putting off making decisions. } \\
\text { a) Yes } \\
\text { b) No }\end{array}$ & $\begin{array}{l}5 \\
48\end{array}$ & $\begin{array}{l}9.4 \\
90.6\end{array}$ & $\begin{array}{l}9.4 \\
90.6\end{array}$ & $\begin{array}{l}9.4 \\
100.0\end{array}$ \\
\hline $\begin{array}{l}\text { I get tired easily than I used to. } \\
\text { a) Yes } \\
\text { b) No }\end{array}$ & $\begin{array}{l}2 \\
51\end{array}$ & $\begin{array}{l}3.8 \\
96.2\end{array}$ & $\begin{array}{l}3.8 \\
96.2\end{array}$ & $\begin{array}{l}3.8 \\
100.0\end{array}$ \\
\hline $\begin{array}{l}\text { I get annoyed and irritated easily. } \\
\text { a) Yes } \\
\text { b) No }\end{array}$ & $\begin{array}{l}45 \\
8 \\
\end{array}$ & $\begin{array}{l}84.9 \\
15.1 \\
\end{array}$ & $\begin{array}{l}84.9 \\
15.1 \\
\end{array}$ & $\begin{array}{l}84.9 \\
100.0\end{array}$ \\
\hline $\begin{array}{l}\text { I wake up earlier than usual and find hard to sleep. } \\
\text { a) Yes } \\
\text { b) No }\end{array}$ & $\begin{array}{l}32 \\
21\end{array}$ & $\begin{array}{l}60.4 \\
39.6 \\
\end{array}$ & $\begin{array}{l}60.4 \\
39.6 \\
\end{array}$ & $\begin{array}{l}60.4 \\
100.0\end{array}$ \\
\hline $\begin{array}{l}\text { I have lost more weight recently. } \\
\text { a) Yes } \\
\text { b) No }\end{array}$ & $\begin{array}{l}15 \\
38\end{array}$ & $\begin{array}{l}28.3 \\
71.7\end{array}$ & $\begin{array}{l}28.3 \\
71.7\end{array}$ & $\begin{array}{l}28.3 \\
100.0\end{array}$ \\
\hline $\begin{array}{l}\text { My appetite is now worse } \\
\text { a) Yes } \\
\text { b) No }\end{array}$ & $\begin{array}{l}51 \\
2 \\
\end{array}$ & $\begin{array}{l}96.2 \\
3.8 \\
\end{array}$ & $\begin{array}{l}96.2 \\
3.8\end{array}$ & $\begin{array}{l}96.2 \\
100.0\end{array}$ \\
\hline
\end{tabular}


Psychological Impact of Vesico-Vaginal Fistula on Reproductive Age Women and its Midwifery Implication in Lautech Teaching Hospital, Osogbo, Osun State

\begin{tabular}{|c|l|l|l|l|}
\hline $\begin{array}{l}\text { I feel I have failed in life. } \\
\text { a) Yes }\end{array}$ & 26 & 49.1 & 49.1 & 49.1 \\
b) No & 27 & 50.9 & 50.9 & 100.0 \\
\hline $\begin{array}{l}\text { I push myself very hard to do things. } \\
\text { a) Yes }\end{array}$ & 32 & 60.4 & 60.4 & 60.4 \\
b) No & 21 & 39.6 & 39.6 & 100.0 \\
\hline I feel better off dead. & 8 & & & 15.1 \\
a) Yes & 45 & 84.9 & 15.1 & 100.0 \\
b) No &
\end{tabular}

\section{CROSSTABS}

Hypothesis One

The hypothesis states that, 'there is no significant difference in psychological impact of VVF on young respondents compared with middle-age respondents.

Age $*$ The disease has impact on lifestyle \& role performance Cross tabulation

\begin{tabular}{|c|c|c|c|c|c|}
\hline & & & $\begin{array}{l}\text { The dise } \\
\text { role perf }\end{array}$ & pact on lifestyle \& & \\
\hline & & & Yes & $\mathrm{No}$ & Total \\
\hline Age & Young adult (20-40 yrs) & $\begin{array}{l}\text { Count } \\
\% \text { within Age } \\
\% \text { within The disease has } \\
\text { impact on lifestyle \& role } \\
\text { performance }\end{array}$ & $\begin{array}{l}28 \\
90.3 \% \\
59.6 \%\end{array}$ & $\begin{array}{l}3 \\
9.7 \% \\
50.0 \%\end{array}$ & $\begin{array}{l}31 \\
100.0 \% \\
58.5 \%\end{array}$ \\
\hline & Middle adult (40-65 yrs) & $\begin{array}{l}\text { Count } \\
\% \text { within Age }\end{array}$ & $\begin{array}{l}19 \\
86.4 \%\end{array}$ & $\begin{array}{l}3 \\
13.6 \%\end{array}$ & $\begin{array}{l}22 \\
100.0 \%\end{array}$ \\
\hline & & $\begin{array}{l}\% \text { within The disease has } \\
\text { impact on lifestyle \& role } \\
\text { performance }\end{array}$ & $40.4 \%$ & $50.0 \%$ & $41.5 \%$ \\
\hline Total & & $\begin{array}{l}\text { Count } \\
\% \text { within Age } \\
\% \text { within The disease has } \\
\text { impact on lifestyle \& role } \\
\text { performance }\end{array}$ & $\begin{array}{l}47 \\
88.7 \% \\
100.0 \%\end{array}$ & $\begin{array}{l}6 \\
11.3 \% \\
100.0 \%\end{array}$ & $\begin{array}{l}53 \\
100.0 \% \\
100.0 \%\end{array}$ \\
\hline
\end{tabular}

Chi-Square Tests

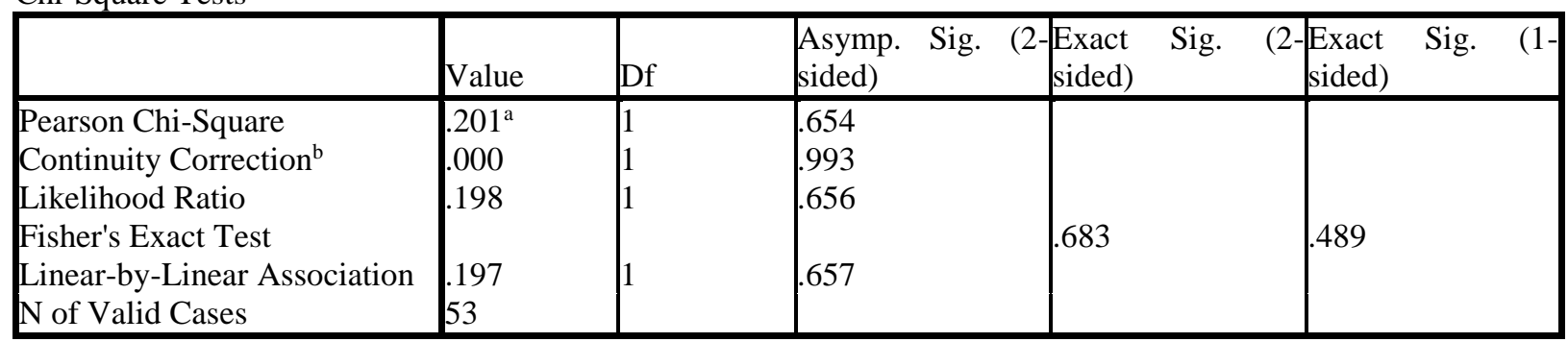


$\mathrm{X}^{2}$ cal $=0.201 ; \mathrm{X}^{2}$ critical $=3.841$ at 0.05 level of significance

Since the table value (3.841) is greater than the calculated value $(0.201)$, the hypothesis is therefore not rejected. This is a new finding, hence not corroborated in the literature review.

\section{Hypothesis Two}

The hypothesis states that, 'there is no significant difference in psychological impact of VVF between educated and illiterate respondents.

Educational Status * The disease condition has impact on sexual activities Cross tabulation

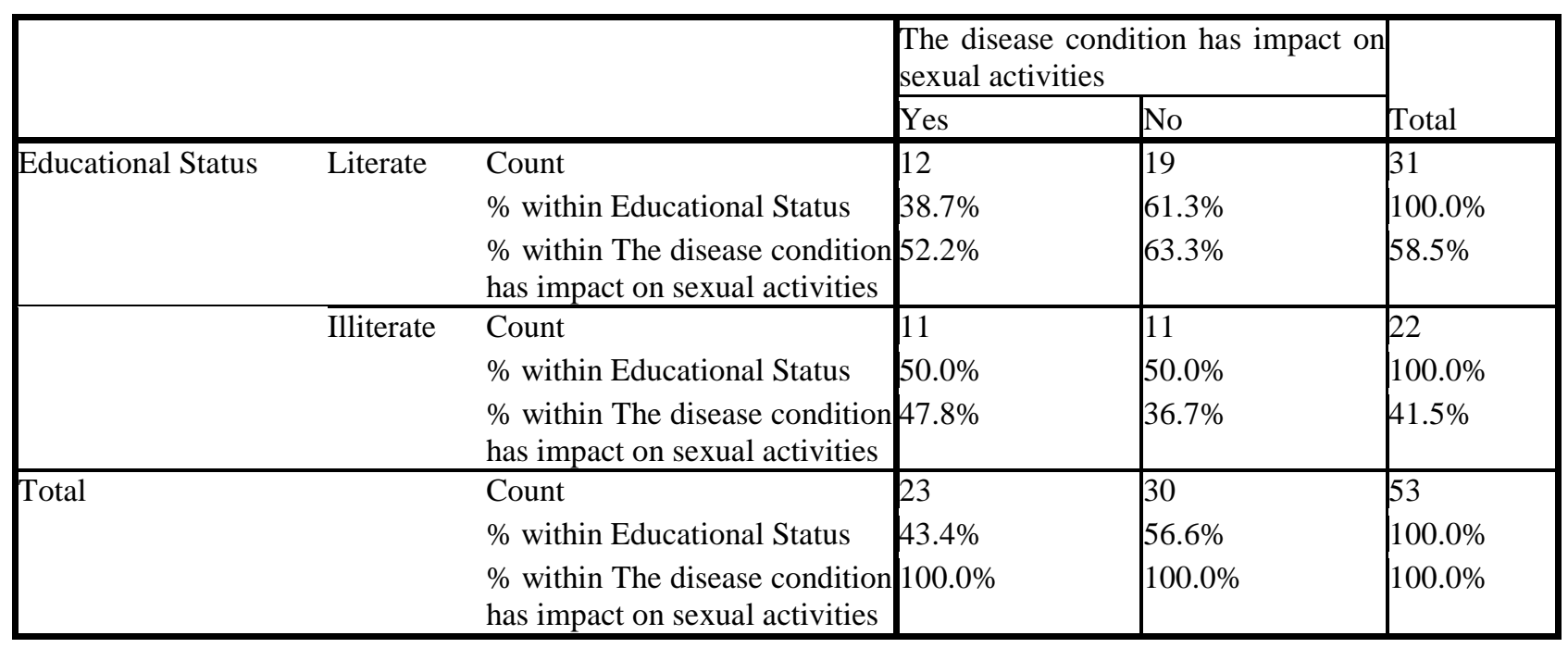

Chi-Square Tests

\begin{tabular}{|c|c|c|c|c|c|}
\hline & Value & Df & \begin{tabular}{|l} 
Asymp. Sig. \\
sided)
\end{tabular} & $\begin{array}{lll}\text { Exact } & \text { Sig. } \\
\text { sided }) & \end{array}$ & $\begin{array}{lll}\text { Exact } & \text { Sig. } \\
\text { sided }) & \end{array}$ \\
\hline $\begin{array}{l}\text { Pearson Chi-Square } \\
\text { Continuity Correction }{ }^{\mathrm{b}} \\
\text { Likelihood Ratio } \\
\text { Fisher's Exact Test } \\
\text { Linear-by-Linear Association } \\
\mathrm{N} \text { of Valid Cases }\end{array}$ & $\begin{array}{l}668^{a} \\
287 \\
667 \\
.655 \\
53\end{array}$ & $\begin{array}{l}1 \\
1 \\
1\end{array}$ & $\begin{array}{l}.414 \\
.592 \\
.414 \\
.418\end{array}$ & .574 & .296 \\
\hline
\end{tabular}

$\mathrm{X}^{2}$ cal $=0.668 ; \mathrm{X}^{2}$ critical $=3.841$ at 0.05 level of significance

Since table value (3.841) is greater than calculated value (0.668), the hypothesis is therefore not rejected. This is also a new finding that is not corroborated in the literature review.

\section{Hypothesis Three}

The hypothesis states that "there is no significant difference in psychological impact of VVF between respondents from urban and rural area.

Place of abode * I get annoyed and irritated easily Cross tabulation 


\begin{tabular}{|c|c|c|c|c|c|}
\hline & & & \multicolumn{2}{|c|}{ I get annoyed and irritated easily } & \multirow[b]{2}{*}{ Total } \\
\hline & & & Yes & No & \\
\hline \multirow[t]{2}{*}{ Place of abode } & Rural area & $\begin{array}{l}\text { Count } \\
\% \text { within Place of abode } \\
\% \text { within I get annoyed and } \\
\text { irritated easily }\end{array}$ & $\begin{array}{l}3 \\
33.3 \% \\
6.7 \%\end{array}$ & $\begin{array}{l}6 \\
66.7 \% \\
75.0 \%\end{array}$ & $\begin{array}{l}9 \\
100.0 \% \\
17.0 \%\end{array}$ \\
\hline & Urban area & $\begin{array}{l}\text { Count } \\
\% \text { within Place of abode } \\
\% \text { within I get annoyed and } \\
\text { irritated easily }\end{array}$ & $\begin{array}{l}42 \\
95.5 \% \\
93.3 \%\end{array}$ & \begin{tabular}{|l|}
2 \\
$4.5 \%$ \\
$25.0 \%$
\end{tabular} & $\begin{array}{l}44 \\
100.0 \% \\
83.0 \%\end{array}$ \\
\hline Total & & $\begin{array}{l}\text { Count } \\
\% \text { within Place of abode } \\
\% \text { within I get annoyed and } \\
\text { irritated easily }\end{array}$ & $\begin{array}{l}45 \\
84.9 \% \\
100.0 \%\end{array}$ & $\begin{array}{l}8 \\
15.1 \% \\
100.0 \%\end{array}$ & $\begin{array}{l}53 \\
100.0 \% \\
100.0 \%\end{array}$ \\
\hline
\end{tabular}

Chi-Square Tests

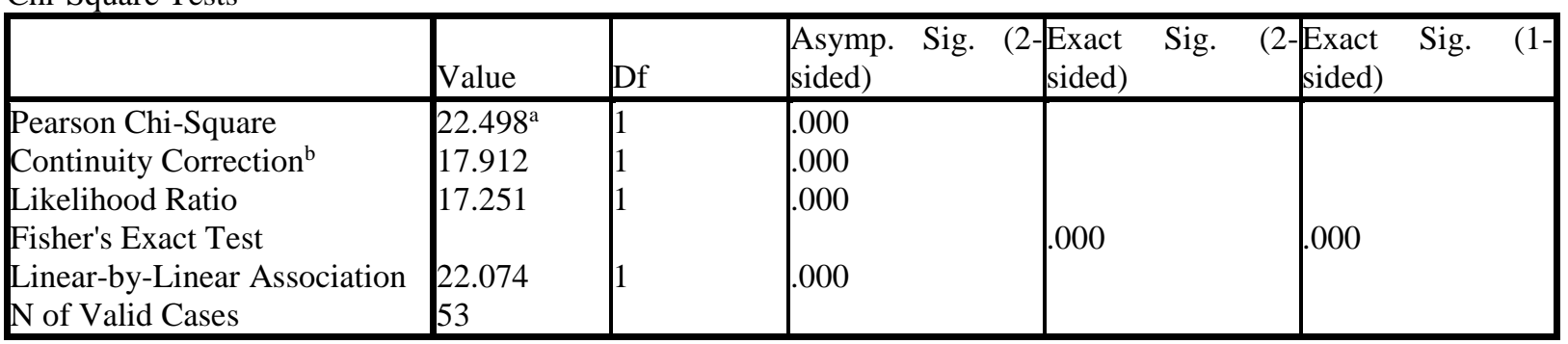

$\mathrm{X}^{2}$ cal $=22.498 ; \quad \mathrm{X}^{2}$ critical $=3.841$ at 0.05 level of significance

Since the table value (3.841) is less than calculated value (22.498), the hypothesis is rejected and restated as "there is significant difference in psychological impact of VVF between respondents from urban and rural areas. This finding corroborates with citing in (http://www.ncbi.nlm.nih.gov/pubmed; Accessed January 7, 2012) which opined that in rural areas, the prevalence rate is higher due to inadequacy of facilities for pre-natal and post-natal care. In such areas, long distances combined with high cost of care, ignorance and poor nutrition makes women more vulnerable to VVF.

\section{Midwifery implication}

The findings from the study has shown that VVF patients are faced with a lot of psychological problems, it therefore becomes imperative for midwives to be aware of the various psychological problems encountered by VVF patients.

The midwife uses her knowledge to design and plan an individualized care to ameliorate such psychological problems. The midwife must understand that the problems faced by VVF patients will affect their lifestyle and behaviour. As soon as the patient is admitted, the midwife should use her knowledge of interpersonal relationship to know the personality and coping styles of her patients. The understanding of this will assist the midwife in determining when the coping strategy of her patient is no more effective as a result of over-ridden effect of the disease condition.

The findings of the study have made it mandatory for all midwives to learn some techniques in psychotherapy that will assist them in the care of VVF patients with psychological problems. The midwife must be trained on several techniques that can be used to limit the psychological problems associated with VVF from the first day of admission. The patient should be taught about the management and positive health habits associated with VVF. This becomes necessary as education will increase the awareness of patients on the psychological and physiological effects of VVF and the available care the patient will undergo.

The midwife should not wait until the patient develops psychological problems before offering psychological support. A sort of 'electic' midwifery approach should be adopted in the care of VVF 
patients. Midwives should not neglect the patient and a strong interpersonal relationship should exist between the midwife and the patient because this limits the effect of the disease condition on the psychological status.

Midwives must be aware of and understand their own emotional problems and tackle them so that they do not reflect in their care of the patient, thereby further aggravating the problem.

\section{CONCLUSION AND RECOMMENDATION}

The research serves as an eye opener to the collective effect of VVF on the psychological status of patients. It is evident that patients are challenged in a devastating way and the relationship of these challenges complicate the effort a patient makes towards living a normal life. It is also evident that the understanding of the effect of these challenges by all the parties involved in the care of the patient which includes the patient's family, care giver and the society will go a long way in eliminating the psychological problems that VVF patients experience. Further studies can be carried out to know the effect which psychotherapeutic package, examples which include psychotherapy, motivational therapy, occupational therapy, diversional therapy etc, have on VVF patients and also the physiological impact of VVF on reproductive-age women.

\section{CONFLICT OF INTEREST}

The author has not declared any conflict of interest.

\section{ACKNOWLEDGEMENTS}

The author would like to thank God for making this research a reality as well as her supervisor, Dr. B.L. Ajibade and Head of department of Nursing, LAUTECH, Dr. Tijani for their encouragement and effective guidance. The author also appreciates her lovely parents, Mr. and Mrs. Olatunde, her sister, Olatunde Adeola for their moral and financial support as well as her entire friends, most especially Abiodun Fatokunbo, Vincent Hinmikalu, Bayo Giwa and Fatoye Temitope for their daily encouragement. God bless you all.

\section{REFERENCES}

1) Barbara, K., Glenora, E., Audrey, S. and Shirlee, F. (2004) Fundamentals of Nursing 7th ed. New Jersey: Pearson.

2) Eileen, P.K. and Vicki, R.A. (2003). Nursing intervention and clinical skills. $3^{\text {rd }}$ ed. USA: Elsevier.

3) Famakinwa, T.T. (2003). A synopsis of medical-surgical Nursing. $2^{\text {nd }}$ ed. Nigeria: Krisbec

4) Fraser, D., Cooper, M. and Nolt.A. (2006). Myles textbook for midwives. $14^{\text {th }}$ ed. New York: Churchill living stone.

5) Hinchliff, S.A. (2004). Dictionary of Nursing. $24^{\text {th }}$ ed. New York: Churchill living stone.

6) Martins, E.F. (2003). Concise medical Dictionary. $6^{\text {th }}$ ed. New York: Oxford University press.

7) Newell, P.W. (2005). Nursing and health management. $7^{\text {th }}$ ed. London: Lippincott Williams.

8) Russel, R., Williams, N. and Bullstrade J. (2004).Shor practice of surgery. $24^{\text {th }}$ ed. U.S.A: Edward Arnold.

9) Smeltzer, C.S. and Bare, B.B. (2004). Brunner and Suddaths textbook of medical-surgical

10) Nursing. $11^{\text {th }}$ ed. London: Lippincott Williams and Wilkins.

11) Taylor, S.B. (2003). Health psychology. $5^{\text {th }}$ ed. Boston: Mcgraw hill.

12) Westtine, N. (2004, January 7). Impact of vesico-vaginal fistula.Retrieved from

13) http://www.ncbi.nlm.nih.gov.

14) Williams, S.D. (2003, January 8). Concept of vesico-vaginal fistula.Retrieved from

15) http://www.urology web.Com 